\title{
Quality and Validity Examination of Academic Paper in the Legislation of Local Regulation about Mining Management and Business
}

\author{
Muhammad Dahlan \\ Lecturer at the Faculty of Law, \\ Researchers at the Center for the Study of Human Rights and \\ Democracy Faculty of Law \\ University of Brawijaya \\ Malang, Indonesia \\ dahlan@ub.ac.id
}

\author{
Herlin Wijay ati \\ Lecturer at the Faculty of Law. \\ Researchers at the Center for the Study of Human Rights and \\ Democracy Faculty of Law \\ University of Brawijaya \\ Malang, Indonesia \\ gsa115@ub.ac.id
}

\begin{abstract}
At present the main challenges faced by governments and local governments in mineral and coal mining are the influence of global interests that drive democratization, regional autonomy, human rights, the environment, technological and information development, intellectual property rights and demands for increasing the role of the private sector and society. This influence can be achieved (among other things) by maintaining the quality of the process of drafting local regulations that have an impact on the quality of the substance of the regional regulations. In terms of preparing academic texts as philosophical, sociological and juridical legitimacy in the preparation of regional regulations on mining, it is necessary to conduct a appropriateness test or quality test of the academic text, given the impact of mining arrangements are concerning safety, welfare and justice for the general public. Based on the description in this background, the author examines the "Quality and Validity Examination of Academic Papers in the Legislation of Local Regulation about Mining Management and Businesses". The type of research used is normative legal research, namely legal research that examines the contents of Article 43 (3), Article 56 section (2), and Article 63 of Law Number 12 of 2011 concerning Establishment of Legislation. Thus, the approach taken in this study is the statute approach, conceptual approach and historical approach.
\end{abstract}

Keywords-local regulation, mining management and business, validity and quality examination

\section{INTRODUCTION}

The State of Indonesia is a state of law, the basic idea in the state that emerged from the founding people is clearly stated in Article 1 section 3 of the 1945 Constitution of the Republic of Indonesia which states that "the State of Indonesia is a legal state"[1]. This provision has the meaning that the State of Indonesia makes the law as the main guideline or the main foundation in its state administration life, as well as making the 1945 Constitution of the Republic of Indonesia as the basic law or constitution that forms the basis for the establishment of the legislation, under Indonesia's People's Consultative Assembly authority to consider amending The Constitution[2]. In this condition, the law occupies the highest position (supremacy of law), then becomes the basis for treating every citizen (equality before the law), and guarantees certainty of treatment for every citizen (legality principle, due process of law).

The 1945 Constitution of the Republic of Indonesia as a constitution or basic law regulates the order of state administration life as an outline, and requires more detailed and more operational derivative legis lation. Derivative legal norms that function as executors of the contents of the 1945 Constitution of the Republic of Indonesia are hierarchically regulated in Article 7 section (1) of Law Number 12 of 2011 concerning the Establishment of Legislation (P3), the hierarchy has the effect that the types of regulations that are inferior (bottom) may not conflict with the type of regulation that has a superior (above) position, based on the principle of lex superiori derogate legi inferiori [3].

In addition to regulating the hierarchy of laws and regulations, Law No. 12 of 2011 concerning Establishment of Legislation also regulates procedures for a good and proper formation of a regulation, this can be seen in Article 16 and so on which states that the process of forming legislation starts from planning, drafting, discussing, ratifying or stipulating, and enacting. This process is regulated with the spirit to keep the contents of each regulation is fulfilling the aspirations of the community, appropriate and it has exact aim, and does not lead to multiple interpretations and norm conflicts, both horizontally and vertically. The establishment of good laws and regulations will also contribute well to the achievement of the objectives of the state of law which prosper the people.

One of the arrangements in Law No. 12 of 2011 concerning Establishment of Legislation which has progressive value and is very important is an obligation to include an academic paper or preparatory paper for each draft of legislation and draft of regulations for provincial and district / city regions. The obligation to include academic paper or preparatory paper is considered very important because its presence is something new and is expected to create a participatory legal product, in accordance with what has been explicitly regulated in several articles in this Act. ${ }^{1}$ The process of community involvement and aspiration

Law Number 10 of 2004 concerning the establishment of Legislation that has been abolished has not clearly regulated the position of the academic Paper. 
capturing as well as extracting legal facts as a basis for analysis, become an important point in the preparation of academic paper which will be a reference to the substance of the draft of law or draft of regional regulations that will be made at a later stage.

In Article 1 point 11 of Law Number 12 of 2011 concerning Establishment of Legislation stated that "Academic paper is the result of research or legal review and other research results on a particular problem that can be accounted for scientifically regarding that particular problem in a Draft of Law, Draft of Regulation for Provincial Region, Draft of Regulation for District / City Regional as a solution to the problems and legal needs of the community". From this understanding it can be understood that academic paper are one of the main steps in the formulation of draft regulations, based on real research that reveals real problems, then it is given the right solution, so that the draft of regulations that will be discussed and approved and later enacted will be really effective and provide justice, usefulness, and legal certainty to the community.

Furthermore, Article 43 section (3) of the Establishment of Legislation Law states that the Draft of Law derived from the House of Representatives (DPR), the President, or the Regional Representative Council (DPD) must be accompanied by an Academic Text, then in Article 56 section (2) it is stated that the Draft of Regulation for Provincial Region as referred to in section (1) of this article is accompanied by an explanation or information and/or Academic Text. Even so with Article 63 stipulates that the provisions concerning the preparation of Draft of Regulation for Provincial Region as referred to in Article 56 to Article 62 apply mutatis mutandis to the preparation of Draft of Regulation for District / City Regional. Mutatis muntandis means that the legal norms referred to (in this case Article 56) are applied equally to legal objects subject to rules, namely Regulation for District / City Regional.

The interesting thing that arises from the arrangement of Article 43 section (3), Article 56 section (2), and Article 63 of Law Number 12 of 2011 concerning the Establishment of Legislation is the legal position of the academic text. There is a difference in the legal language used in those articles. If observed, Article 43 section (3) states the words "must be accompanied by an Academic Text", then Article 56 section (2) mentions the word "accompanied by an explanation or information and/or Academic Text". Does the difference in words have different legal meanings that cause different legal effects, or does the difference in words not cause a difference in legal meaning, so that the legal impact that will arise is the same?

As we know that the law has its own language which is sui generis (following the nature of the law itself)[4]. Every word and sentence in the law has a special understanding that should not be deviated or interpreted in a double way, so it is natural for legal scientists to require good legal norms to be legal norms that do not have double or multiple interpretations.The word 'must be accompanied' and 'accompanied' literally has a different degree of mandatory, but perhaps in Law No. 12 of 2011 concerning the Establishment of Legislation the two words have the same meaning. Well, reviewing this is a legal study that has an impact on the understanding that every reader and user of the law should have. This study focuses on the value of the mandatory to include academic texts in each Draft of Regional Regulation that regulate mining, including mining management and business. Article 7 section (1) and Article 8 section (1) of Law Number 4 of 2009 concerning Mineral and Coal Mining states that the Regional Government has the authority to make regional regulations on mining.

Normative legal research on this case refers to the use of secondary data. While the legal material used by the researcher rests on primary, secondary and tertiary legal materials[5]. Primary legal material consists of several laws and regulations, including:

a) The 1945 Constitution of the Republic of Indonesia.

b) Law Number 32 of 2004 concerning Regional Government.

c) Law Number 12 of 2011 concerning Establishment of Legis lation.

Minister of Home Affairs Regulation Number 53 of 2011 concerning Guidelines for Establishing Regional Legal Products.

\section{DISCUSSION}

\section{A. Definition and Arrangement of Academic Paper}

The term Academic Paper is not a single term used so far, because in the literature and legal documents official terms are known, including:

a. Academic Design (as used in Presidential Decree No.88 of 1998 concerning Procedures for Preparing the Draft of Law and Draft of Government Regulation)

b. Academic Draft

c. Early Paper of Draft of Law $(R U U)$ / Draft of Government Regulation (RPP)

d. Academic Paper

e. Academic Paper (based on Presidential Regulation Number 68 of 2005 concerning Procedures for Preparing the Draft of Law, Draft Government Regulation in Lieu of Law, Draft Government Regulation, and Draft Presidential Regulation).

In accordance with the use of the term in Law Nu mber 12 of 2011 concerning Establishment of Legislation, the author in this case uses the term "Academic Paper".

The Academic Paper contains ideas that are futuristic and solutional for the regulation of a legislative material in a legal field. This idea arose after first being carried out comprehensively in a normative and sociological study from various dimensions of science (multidisciplinary and interdisciplinary). The Academic Paper also contains recommendations about the need for a law to be established.

Article 18 of Law Number 10 of 2004 concerning Establishment of Legislation states:

(1) The draft of law submitted by the President is prepared by the Minister or the head of a nondepartmental government institution in accordance with the scope of duties and responsibilities.

(2) Harmonization, rounding and strengthening of the concept of the draft of law derived from the President, coordinated by the minister whose duties and responsibilities are in the field of legislation. 
(3) Further provisions regarding the procedure for preparing the draft of law as referred to in section (1) shall be regulated by a Presidential Regulation.

Article 18 section (3) as stated above explicitly mandates the need to make implementing regulations in the form of a Presidential Regulation. The Presidential Regulation referred to is Presidential Regulation Number 68 of 2005 concerning Procedures for Preparing the Draft of Law, Draft of Government Regulation in Lieu of Law, Draft of Government Regulation, and Draft Presidential Regulation. In Article 5 of the Presidential Regulation Number 68 of 2005 regulates the Academic Paper, as follows:

1) The initiator in preparing the Draft of Law can first compile an Academic Paper concerning the material to be regulated in the Draft of Law.

2) Preparation of Acade mic Paper as referred to in section (1) is carried out by the Initiator together with the Department whose duties and responsibilities is in the field of legislation and its implementation can be submitted to universities or other third parties who have expertise for it.

3) Academic Paper as referred to in section (1) shall at least contain the philosophical, sociological and juridical basis, principal and scope of the material to be regulated.

4) Gu idelines for preparing Acade mic Texts are regulated by a Ministerial Regulation.

The settings in the Presidential Regulation is actually not much different from the previous provisions contained in Presidential Decree Number 188 of 1998 concerning Procedures for Preparing the Draft of Law and Draft of Govern ment Regulation. Article 3 of this Presidential Decree states:

(1) The Minister or Chairpers on of the Institution initiating the drafting of the Draft of Law can also first prepare an academic draft regarding the Draft Law to be arranged.

(2) The preparation of an academic design is carried out together with the Department of Justice and its implementation can be submitted to Universities or other Third Parties who have expertise for it.

Furthermore, in Article 4 number (2) it is affirmed that in the case that the Draft of Law requires an Academic draft, the academic draft as referred to in article 3 section (1) is used as material in the discussion of the consultation forum.

The word "can" in the formulation of Article 5 of the Presidential Regulation Number 68 of 2005 and in Article 3 section (1) of Presidential Decree 188 of 1998 means that the Academic Paper does not have to be made for a plan to submit a draft of law. This means that the preparation of a draft of law may be with or without proceeded by the preparation of the Academic Paper. The implication of this arrangement is the large number of draft of laws submitted without accompanied by Academic Paper, because indeed the nature is not mandatory. The regulation stipulates that the preparation of the Academic Paper for its implementation can be submitted to Universities or Third Parties. Thus, universities, research institutions and legal studies, nongovernmental organizations, and community organizations can make the Academic Paper for a draft of law either through collaboration with the technical department or on its own initiative.
The next problem is the absence of uniformity in the academic paper format (before the era of Law Number 12 of 2011 concerning the Establishment of Legislation), so that it has a negative impact. The absence of uniformity in the preparation of the Academic Paper has become an obstacle and polemic for leg islation scientist and legislative drafting practitioners.

Clarity regarding the position and format of the new academic paper found in Annex I of Law Nu mber 12 of 2011 concerning Establishment of Legislation stated that the Academic Paper is a research result or legal assessment and other research results on a particular problem that can be accounted for scientifically regarding the arrangement of the problem in a Draft of Law, Draft of Regulation for Provincial Region, Draft of Regulation for District / City Regional, as a solution to the problems and legal needs of the community.

Systematic of Academic Paper are as follows:

- Title

- Foreword

- Table of contents

1. Chapter I Introduction

2. Chapter II Theoretical Study and Empirical Practices

3. Chapter III Evaluation and Analysis of Related Legislation and Regulations

4. Chapter IV Philosophical, Sociological, and Juridical Foundation

5. Chapter V Reach, Direction of Arrangement, and Scope of Content Material of Law, Regulation for Provincial Regional, or Regulation for District / City Regional

6. Chapter VI Closing

Bibliography

- Appendix: Legislation Draft

B. Position of Academic Paper in the formation of laws and regulations based on Law No. 12 of 2011 concerning the Establishment of Legislation

The background to the regulation regarding the position and format of the academic paper in Law Nu mber 12 of 2011 concerning the Establishment of Legislation is the claim of imperfection in the material of Law Number 10 of 2004 concerning the Establishment of Legislation. There is agreement from various parties to make improvements to this Law, so that a better law is created and has minimized deficiencies in various articles of the old Law. In-depth steps and efforts of assessment have been carried out until a better concept is found related to the formation of legislation as a whole. The concrete result of the reform effort is the establishment of Law Number 12 of 2011 concerning the Establishment of Legis lation.

The process of forming legislation is a series of activities carried out continuously between one and the next to form a legislation. This formation process begins with the first step to find an idea about the need for regulation of a problem, and then proceeded with the steps as stipulated in Article 1 number 1 of Law Number 12 of 2011 concerning Establishment of Legis lation.

There it is explained that what is meant by the formation of legislation, starts from planning, preparation, and 
techniques for compilation, formulation, discussion, ratification, enactment, and dissemination. The second stage in the formation of legislation is the preparation stage. In this preparation stage there are several important activities that are regulated in this draft of law, namely the preparation of the Academic Paper. The Academic Paper contains academic thoughts on the substance of the legislation formulated. The Academic Paper is very helpful for the government and the members of representatives or anyone involved in the establishment of the legislation, because all scientific data, information and thoughts related to the substance are collected in this Academic Paper document.

To be able to realize a process of establishing good laws and regulations, it is necessary to have an instrument of regulation that can be used as a guideline and reference for parties in the formation of laws and regulations, both at the central and regional levels. Law Number 12 of 2011 concerning the Establishment of Legislation is a written regulation instrument that provides technical guidance on the preparation and framework for legislation, so that it is hoped that it can create order in the form and format of the formation of laws and regulations, both at the central and regional levels.

The Academic Paper is not something new, especially in the process of establishing legislation. On December 29, 1994, the National Law Development Agency (BPHN) formed a technical guide to the preparation of the Academic Paper, this through a Decree of the Head of the National Law Development Agency No. G-159.PR.09.10 of 1994 concerning Technical Guidelines for Preparing Academic Paper for Legislation. This decree contains material about the name/term, form and content, position and format of the Academic Text.

The next arrangement regarding academic paper can be known through Presidential Decree (Keppres) Number 188 of 1998 concerning Procedures for Preparing the Draft of Law which states the term Academic Paper with the mention of "Academic Design". In Article 3 section (1) of the Presidential Decree Number 188 of 1998 stated that "the Minister or the head of the institution that initiate the Draft of Law can also first prepare an academic draft regarding the Draft of Law to be prepared". Next, in Law Number 10 of 2004 concerning Establishment of Legislation, it is not clearly regulated regarding Academic Paper.

The Academic Paper only "appears" explicitly through Presidential Regulation Number 68 of 2005 concerning Procedures for Preparing the Draft of Law, Draft of Government Regulation and Draft of Presidential Regulation. Article 5 sections (1) of Presidential Regulation Number 68 of 2005 states that: "The initiator in drafting the Law can first prepare an Academic Paper concerning the material to be regulated in the Draft of Law". Then in Article 5 section (2) Presidential Regulation Number 68 of 2005 states that "Preparation of Academic Paper as referred to in section (1) is carried out by the initiator together with the Department whose duties and responsibilities in the field of legislation and their implementation can be submitted to universities or other third parties who have expertise for that".

The position of the Academic Paper in this period has not yet led to the conditions of the obligation/mandatory in the context of drafting the legislation. The position of the
Academic Paper is still considered only as a "supporter" in the preparation of legislation. However, with the growing and changing patterns of life of the Indonesian people as well as some problems in the making and implementation of existing legislation, the urgency of the Academic Paper in the process of drafting legislation that is effective, comprehensive and in accordance with the principles of legislative formation invitations are becoming very important.

In the academic paper of the latest Establishment of Legislation draft (Law No. 12 of 2011 concerning Establishment of Legislation stated that the need for the preparation of an academic paper is something that cannot be ignored, even requiring strict arrangements, although still paying attention to real conditions. This is perhaps what's becoming the basis of the difference the word "must be accompanied" and "accompanied" in article 43, 56, and 63 of Law Number 12 of 2011 concerning Establishment of Legislation. The word must be accompanied by a stronger emphasis than just accompanied, although it turns out that almost all scientists and legal practitioners agree that the position of the academic paper in the draft of law and draft of regional regulations are equally mandatory.

Emphasis on this obligation is based on the desire to explore legal facts and community needs related to the preparation of a legal product that is a scheme (regeling), and provides space for active participation of the community. Laws, especially legislations and regional regulations, contain rights and obligations that will be borne by the community. Even in both regulations, a formulation of criminal act can be included that can be threatened and imposed on each person who violates it.

Therefore, the legislation is very closely related to the interests of the community. With this frame work of thoughts, community participation in formulating norms that burden rights and obligations to them is very important. Therefore, the establishment of Law Number 12 of 2011 concerning Establishment of Legislation feels that it is necessary to regulate provisions regarding academic papers and community participation specifically and need to be regulated in a separate chapter[6]. In connection with that, the community has the right to provide input orally or in writing in the Establishment of Legislation. Besides that, it is necessary to regulate the mechanism for providing input. Some methods that should be considered and outlined in this regard are public hearings; work visit; and/or seminars/workshops/discussions.

Whereas the community is meant in an individual; community groups/organizations; professional group; universities; non-governmental organization; cultural society; and/or other stakeholders. To make it easier for the public to provide input orally or in writing, this law stipulates that each draft of law can be easily accessed by the community.

The urgency of arranging academic papers can be found in the description of the explanation of Law Number 12 of 2011 concerning Establishment of Legislation which states that as an effort to improve the previous Law, there is a new content material added to this Law, namely:

a) the arrangement of the Academic Paper as a requirement in the preparation of the Draft of Law, 
Draft of Regulation for Provincial Region, Draft of Regulation for District / City Regional;

b) regulation regarding the participation of Legislation Designers, researchers and experts in the Formation of a Legis lation; and

c) addition of techniques for preparing Academic Scripts in Attachment I of this Law.

Regulation on academic papers in Law No. 12 of 2011 concerning Establishment of Legislation is a good opportunity, but there are 2 challenges to weight-up the quality of academic papers, especially in the regulation of mining in the regions. First, the fact that the academic paper is only attached to the draft of regional regulation, without a strong phrase stating that its presence is an obligation, must be amended by a stricter arrangement, stating the obligatory or mandatory of preparation of an academic text. Secondly, without a mechanism for examine the validity and quality of its contents, it has the impact of the number of regional regulations affected by harmonization by the Ministry of Home Affairs of the Republic of Indonesia, as well as the many reviews from civil society stating that some regional regulations in some regions do not adequately regulate human rights issues, justice and community involvement in the policy making process, as well as natural resource management which aims to improve community welfare [7].

Moving on from this analysis, it is necessary to make an effort to reform Law No. 12 of 2011 concerning P3 with the addition of mechanism to exam validity and quality of academic papers of a draft of legislation, especially in the draft of local regulations about mining management and business. The mechanism to exam the validity and quality as well as harmony between the substance of the academic paper and the draft of local regulations is appropriate if placed in the second phase of legislation steps, namely the preparation of academic papers and draft of regional regulations. Experts in regulated fields combined with community representatives and academics representatives can be made a group of judges who will conduct scientific assessments. Of course the basis of this exam of validity and quality is how far the academic paper of the draft of local regulation about mining management and business is prepared based on indicators of democratization, regional autonomy, human rights, the environment, technological and information development, intellectual property rights and demands for increasing the role of private and public.

\section{REFERENCES}

[1] "The 1945 Constitution of the Republic of Indonesia." [Online]. Available: www.ilo.org/wcmsp5/groups/public/---ed_protect/--protrav/---ilo_aids/documents/legaldocument/wcms_174556.pdf.

[2] "Indonesia: Constitutional Amendment to Be Considered." [Online]. Available: https://www.loc.gov/law/foreignnews/article/indonesia-constitut ional-amendment-to-beconsidered/.

[3] "Oxford Reference." [Online]. Available: http://www.oxfordreference.com/view/10.1093/acref/9780195369 380.001.0001/acref-9780195369380-e-1282.

[4] T. T. Tutik, "Ilmu Hukum: Hakekat Keilmuannya ditinjau dari Sudut Filsafat Ilmu dan Teori Ilmu Hukum," J. Huk. dan Pembang., vol. 43rd, no. 2 April-Juni, 2013.

[5] S. Soekanto and S. Mamudji, Nomative Legal Research: A Brief Review. Jakarta: CV Rajawali, 1986.

[6] Academic Paper of the Draft of Law concerning the Establishment of Legislation, House of Representatives'Legislation Body. 2010.

[7] "No Title." [Online]. Available: www.kemendagri.go.id/media/filemanager/2016/06/21/b/a/batal_p erda_21_juni_2016.pdf. 